\title{
100,000-Mile Evaluation of Transit Buses Operated on Biodiesel Blends (B20)
}

\author{
Kenneth Proc, Robb Barnitt, R. Robert Hayes, Matthew Ratcliff, and Robert L. McCormick \\ National Renewable Energy Laboratory-U.S. Department of Energy \\ Lou Ha \\ Regional Transportation District \\ Howard L. Fang \\ Cummins, Inc.
}

Copyright $\odot 2006$ SAE International

\section{ABSTRACT}

Nine identical 40-ft. transit buses were operated on B20 and diesel for a period of two years - five of the buses operated exclusively on B20 (20\% biodiesel blend) and the other four on petroleum diesel. The buses were model year 2000 Orion V equipped with Cummins ISM engines, and all operated on the same bus route. Each bus accumulated about 100,000 miles over the course of the study. B20 buses were compared to the petroleum diesel buses in terms of fuel economy, vehicle maintenance cost, road calls, and emissions. There was no difference between the on-road average fuel economy of the two groups $(4.41 \mathrm{mpg})$ based on the inuse data, however laboratory testing revealed a nearly $2 \%$ reduction in fuel economy for the B20 vehicles. Engine and fuel system related maintenance costs were nearly identical for the two groups until the final month of the study. Component replacements near the end of the study on one B20 bus caused average maintenance costs to be higher for the B20 group ( $\$ 0.07$ vs. $\$ 0.05$ per mile). However, engine and fuel system maintenance costs varied widely from bus-to-bus so the $\$ 0.02$ per mile average difference between the two groups is not statistically significant. There was no significant difference in miles between road calls. Analysis of B20 samples during the study period revealed early problems with fuel blending. There also were occasional fuel filter plugging events for the B20-fueled buses that were likely caused by out of specification biodiesel, however the exact cause could not be conclusively determined. Oil analysis results indicate no additional wear metals from the use of B20, with similar rates of TBN and ZDDP decay. Soot levels in the lubricant were significantly lower for the B20 vehicles. Laboratory chassis emissions tests comparing the in-use B20 and petroleum diesel on the CSHVC cycle showed reductions in all measured pollutants, including a reduction in nitrogen oxides.

\section{INTRODUCTION}

Biodiesel is a diesel fuel blending component made from vegetable oil, waste cooking oil, or animal fat by reaction with methanol to form methyl esters. Biodiesel blends are used to reduce petroleum consumption as well as greenhouse gas and pollutant emissions, and to comply with mandates for the use of alternative fuels. Reductions of particulate matter (PM), carbon monoxide (CO), and total hydrocarbon emissions (THC) can be achieved with biodiesel use [1]. Based on life-cycle analysis, the use of biodiesel produces real reductions in petroleum consumption and carbon dioxide $\left(\mathrm{CO}_{2}\right)$ emissions [2]. Energy content per gallon is slightly lower resulting in minor reductions in peak torque and fuel economy, but thermal efficiency is unchanged [3].

There are few quantitative studies of in-use operational performance. Bickel and Strebig [4] report a two-year field trial of B20 use in road maintenance vehicles in Minnesota. Nearly 25,000 gallons of B20 were consumed over roughly 135,000 miles of operation. The B20 vehicles exhibited the same average fuel economy (in miles per gallon) as the diesel control vehicles. Oil analysis conducted at 5,000-mile intervals indicated no unusual engine wear or fuel dilution.

Chase et al. [5] described operation of a heavy-duty, linehaul truck on a blend of $50 \%$ biodiesel and $50 \%$ No. 2 diesel (B50) for more than 200,000 miles. No operational problems were reported, inspection of the engine at the conclusion of the study showed no excessive wear, and tests indicated no injector degradation.

The BIOBUS project was conducted in Montreal from March 2002 to March 2003 [6]. Biodiesel from vegetable oil, animal fat, and waste cooking oil was tested as B5 and B20 in over 150 buses. Engines included primarily mechanically governed 2-stroke and 4-stroke engines 
manufactured by Detroit Diesel Corporation and Cummins, Inc., respectively. The study found no impact of biodiesel on fuel economy or on the cost to maintain fuel pumps and fuel injectors. Problems with low temperature fuel filter plugging were noted for a few specific vehicles. Pollutant emission measurements revealed reductions in $\mathrm{THC}, \mathrm{CO}$, and $\mathrm{PM}$ with no effect or a small increase for $\mathrm{NO}_{\mathrm{x}}$.

Fraer et al. [7] compared operation of cargo vans and truck tractors on B20 and petroleum diesel and performed teardown and analysis of engines and components. After four years of operation and 600,000 miles accumulated on B20, no differences in wear were noted. In comparing maintenance costs between the two groups, only minor differences could be attributed to B20 use.

In this study, nine identical $40-\mathrm{ft}$. transit buses were operated on B20 and diesel for a period of two years five of the buses operated exclusively on B20 and the other four on petroleum diesel. The buses operated in the Regional Transportation District (RTD) fleet in Boulder, Colorado. A quantitative comparison of mileage accumulation, fuel use, road calls, maintenance costs and events, fuel analysis, oil analysis, and pollutant emissions is reported.

\section{OBJECTIVE}

The objective of this study is to compare vehicles operating on B20 and conventional diesel in terms of engine performance, fuel economy, vehicle maintenance, and emissions. The results will help RTD-and other potential biodiesel users-understand the costs and benefits of B20 use, and any changes to maintenance and operating procedures that might be required. The results also will help engine manufacturers in exploring the effects of B20 on engine durability.

Additionally, RTD has specific objectives for its participation in the project. Located at a mile above sea level, RTD operates and maintains a fleet of over 1000 heavy-duty transit buses serving the transportation needs of over 2.5 million people in the Denver Metropolitan area. The high altitude plus the high desert climate-very low humidity, hot in the summer, and cold and snowy in the winter-create unique challenges for RTD bus propulsion systems. Some of the common problems experienced at this area are low vehicle power, incomplete combustion due to lack of oxygen, and engine overheating due to reduced airflow through the radiators.

RTD is working to reduce exhaust emissions from its buses. In evaluating biodiesel, RTD expects to obtain information on the operation of biodiesel to help its planning of a strategy for improving RTD fleet operating conditions and public image through vehicle emissions reduction, use of renewable fuel, and fleet reliability. This information includes:
- Verification of the emissions benefits of biodiesel

- Performance changes in buses operating on biodiesel

- Fuel consumption changes with biodiesel

- Effects of biodiesel on bus mechanical reliability and service availability

- High altitude and cold weather performance and stability of biodiesel

- Drivers and passengers acceptance of biodiesel.

B20 has typically cost more than No. 2 diesel, and at the time of the evaluation, averaged $\$ 0.17$ higher in the Denver, Colorado, area. As of August 24, 2006, B20 averaged $\$ 2.62$ in the United States compared to $\$ 2.44$ for No. 2 diesel (taxes not included) [8]. RTD must weigh this additional cost against potential benefits.

\section{APPROACH}

\section{VEHICLE SELECTION}

The vehicles chosen for this study are 40 -ft Orion $V$ transit buses and seat 43 passengers. These buses were selected in part because they operate on a dedicated route. They operate in Boulder, Colorado, on RTD's "Skip" route, a 16.1-mile roundtrip route that provides high-frequency bus service along a heavily traveled corridor. The Skip route is served by the nine buses, which have special exterior graphics showing they are dedicated for the route (Figure 1). Table 1 provides a summary description of the Skip buses.

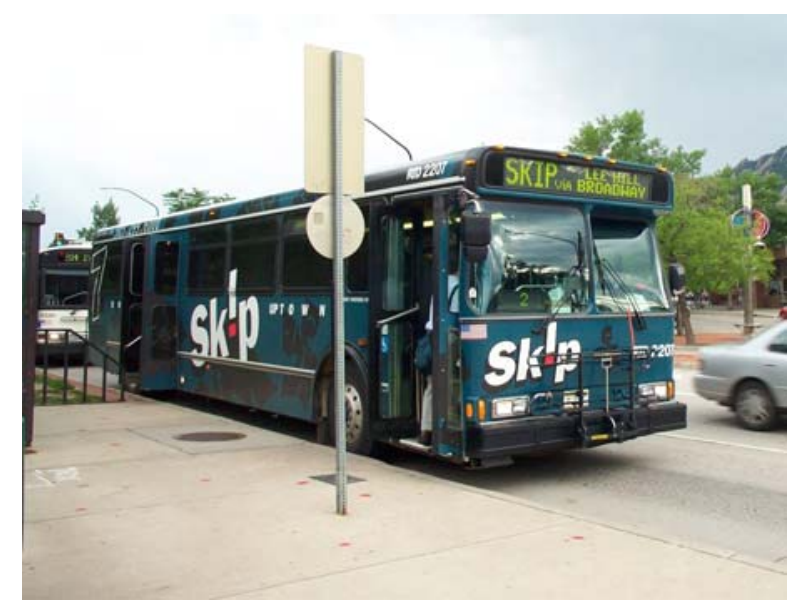

Figure 1. RTD Skip Bus in Service

\section{VEHICLE FUELING}

During this study, five of the nine buses operated on B20, and four operated on standard petroleum diesel as a control group. All buses were fueled daily at which time the hubodometer reading, fuel amount, and amounts of any other fluids added were logged. Diesel buses were fueled at an indoor fueling island, whereas the B20 buses were fueled at a temporary fueling facility located just outside the bus garage (Figure 2). The B20 fueling station contained a 6,000-gallon, above ground storage tank and a pedestal-mounted dispenser. 
Table 1. RTD B20 Evaluation Transit Bus Description Summary

\begin{tabular}{|l|l|}
\hline \multicolumn{1}{|c|}{ Vehicle Information } & \multicolumn{1}{c|}{$\begin{array}{c}\text { Evaluation Buses } \\
\text { (B20 and Diesel) }\end{array}$} \\
\hline Number of Buses & $5 \mathrm{~B} 20,4$ Diesel \\
\hline Chassis Manufacturer/Model & Orion V \\
\hline Chassis Model Year & 2000 \\
\hline Engine Manufacturer/Model & Cummins ISM \\
\hline Engine Model Year & 2000 \\
\hline $\begin{array}{l}\text { Engine Ratings } \\
\text { Max. Horsepower } \\
\text { Max. Torque }\end{array}$ & $\begin{array}{l}280 \mathrm{hp} \mathrm{@} \mathrm{2,100} \mathrm{rpm} \\
900 \mathrm{lb}-\mathrm{ft} @ 1,200 \mathrm{rpm}\end{array}$ \\
\hline Diesel Fuel System Capacity & $125 \mathrm{gal}$ \\
\hline $\begin{array}{l}\text { Transmission } \\
\text { Manufacturer/Model }\end{array}$ & ZF Ecomat 5HP592 \\
\hline Curb Weight & $28,800 \mathrm{lb}$ \\
\hline $\begin{array}{l}\text { Gross Vehicle Weight Rating } \\
\text { (GVWR) }\end{array}$ & $40,600 \mathrm{lb}$ \\
\hline
\end{tabular}

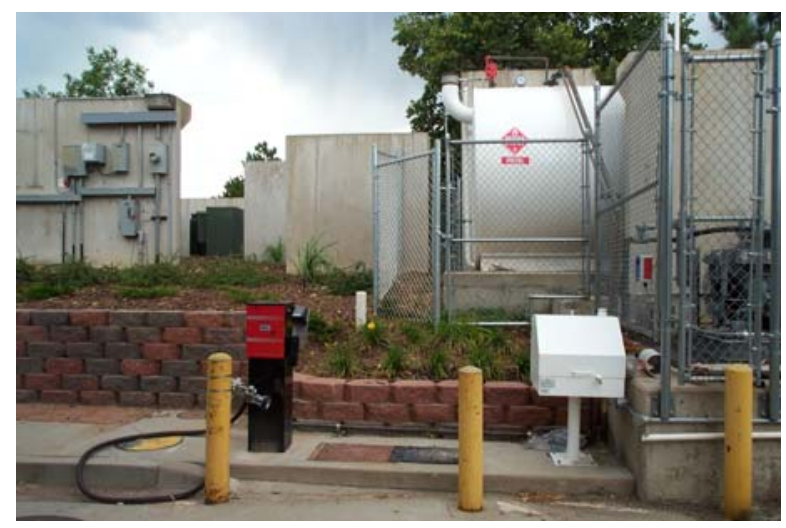

Figure 2. B20 Fueling Station

The buses were fueled using a dry-lock nozzle manufactured by Emco-Wheaton, but to separate fuel types, the B20 buses used a nonstandard connector. The fueling nozzle at the B20 station was identical in appearance and operation to the standard diesel fuel nozzle, but it used a four-pin instead of the standard three-pin connector. This different pin configuration ensured that the test buses were only fueled with B20, and B20 was dispensed only into these buses.

\section{PERIOD OF OPERATION}

RTD has 303 Orion buses in its fleet that entered service beginning in late 2000. In the summer of 2001, nine of the buses were dedicated to the Skip route, and B20 fueling began in July 2004 with each of the buses at about 160,000 miles. By late July 2004 , controlled fueling of the five B20 buses and continuous data collection were in place. The data collection period reported is from August 1, 2004 through July 31, 2006.

\section{DATA COLLECTION AND ANALYSIS}

Operation and maintenance data were collected for 24 months during normal operation and analyzed to evaluate performance. Periodic fuel and used oil samples were collected and analyzed to verify fuel quality and compare oil degradation. On-road fuel economy, maintenance, and road call calculations were based upon records provided by RTD and were reviewed for accuracy by the National Renewable Energy Laboratory (NREL). Each individual event was examined for missing or incomplete information. For example, each fuel record was first checked for data entered in all fields, then for an accurate hubodometer reading (in sequence for a given date), and finally for fuel economy (further examination if grossly out of range). Records that were recorded or entered incorrectly, thereby casting doubt upon their accuracy, were removed from the calculations, thus improving the level of confidence in the on-road data. Results are typically reported as a running or cumulative average, that is, the average results from the beginning of the study to any given point in the study.

\section{CHASSIS DYNAMOMETER EMISSIONS TESTING}

Chassis dynamometer testing allows emissions to be accurately measured in $\mathrm{g} / \mathrm{mile}$ while the vehicle is driven over a reproducible duty cycle in the laboratory. The dynamometer system simulates the vehicle payload as well as aerodynamic drag and rolling resistance. Driving cycles consist of a speed versus time schedule that is followed by the vehicle driver. This study employed a chassis dynamometer consisting of twin 40" rolls connected via gears to a $380 \mathrm{hp} \mathrm{DC}$ dynamometer and to 47" diameter flywheels. The base inertia of the dynamometer system as configured for this testing was approximately $32,000 \mathrm{lbs}$. Additional vehicle inertia, drag, and rolling resistance were simulated using load applied electrically by the dynamometer.

The emissions measurement system employs full scale dilution with constant volume sampling for mass flow measurement. Gaseous emissions-including $\mathrm{CO}_{2}$, nitrogen oxide $\left(\mathrm{NO}_{\mathrm{x}}\right), \mathrm{THC}$, and $\mathrm{CO}$-are measured continuously. PM emissions are measured gravimetrically for samples collected onto $47 \mathrm{~mm}$ Teflon filters and weighed on a microbalance in a clean room environment. The emission measurement system meets the requirements of the current code of federal regulations for heavy-duty engine emissions certification (40 CFR, part 86). In addition, direct mass flow fuel consumption is measured in line with a high accuracy $(+/-0.5 \%$ of reading) fuel metering system, which comprises a volume flow meter and in-line density meter to measure fuel mass flow.

The Skip buses have a rated gross vehicle weight of $40,600 \mathrm{lb}$. For chassis dynamometer testing, a vehicle inertia of $35,000 \mathrm{lb}$ was employed with estimated rolling resistance and drag coefficients set at $\mathrm{C}_{R R}=0.01$ and $\mathrm{C}_{\mathrm{D}}=0.5$. The test driving cycle selected was the CitySuburban Heavy-Vehicle Cycle (CSHVC). This cycle was chosen because certain parameters of the cycle are a close match with the typical Skip bus route, as shown in Table 2. The CSHVC speed-time trace is shown in Figure 3. 
Table 2. Comparison of Parameters for CSHVC and Skip Bus Route

\begin{tabular}{|l|c|c|}
\hline & CSHVC & Skip Route \\
\hline Average Speed, mph & 14.2 & 15.6 \\
\hline Maximum Speed, mph & 44 & 40 \\
\hline Stops per Mile & 0.75 & 0.78 \\
\hline
\end{tabular}

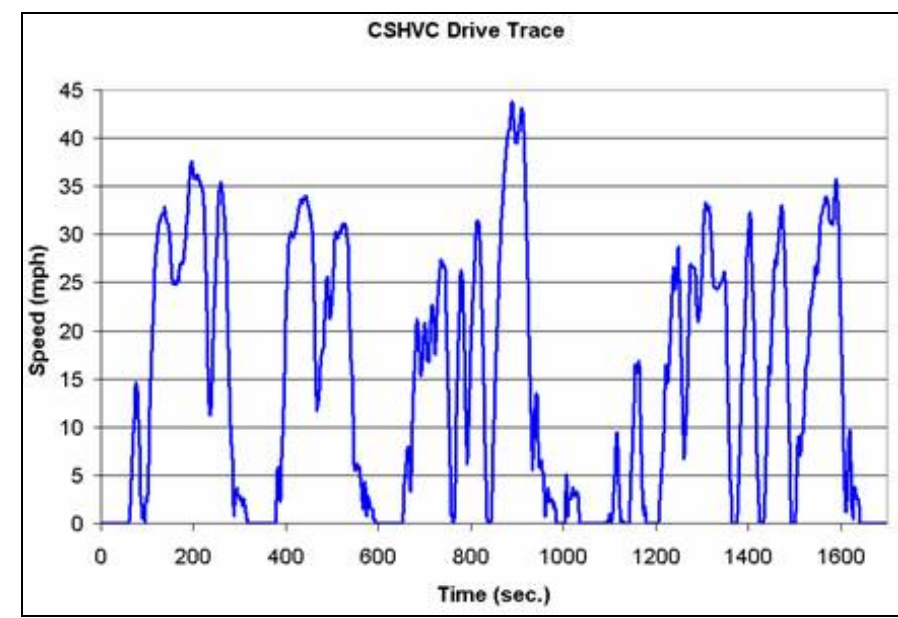

Figure 3. Speed-Time Trace for the CHSVC.

\section{RESULTS}

\section{MILEAGE ACCUMULATION AND FUEL USE}

In the 24 months of data collection, about 100,000 miles were driven by each of the study vehicles. For the B20 buses, more than 100,000 gallons were consumed in total during the study. Table 3 provides mileage accumulation details. The B20 buses had about the same use as the diesel comparison buses. Accumulated mileage numbers are very similar, and both groups averaged over 4,000 miles per bus per month (Figure 4).

Table 3. Accumulated Mileage Details

\begin{tabular}{|c|c|c|}
\hline $\begin{array}{c}\text { Bus } \\
\text { Number }\end{array}$ & VIN & $\begin{array}{c}\text { Total Data } \\
\text { Period } \\
\text { Mileage }\end{array}$ \\
\hline \multicolumn{3}{|c|}{ Diesel Group } \\
\hline 2203 & 1VH5H3H2XY6501249 & 105,499 \\
\hline 2204 & 1VH5H3H2XY6501250 & 106,788 \\
\hline 2205 & 1VH5H3H2XY6501251 & 110,133 \\
\hline 2206 & 1VH5H3H2XY6501252 & 105,981 \\
\hline \multicolumn{3}{|c|}{ B20 Group } \\
\hline 2207 & 1VH5H3H2XY6501256 & 102,614 \\
\hline 2208 & 1VH5H3H2XY6501258 & 100,484 \\
\hline 2209 & 1VH5H3H2XY6501259 & 95,358 \\
\hline 2210 & 1VH5H3H2XY6501260 & 101,815 \\
\hline 2211 & 1VH5H3H2XY6501261 & 100,962 \\
\hline
\end{tabular}

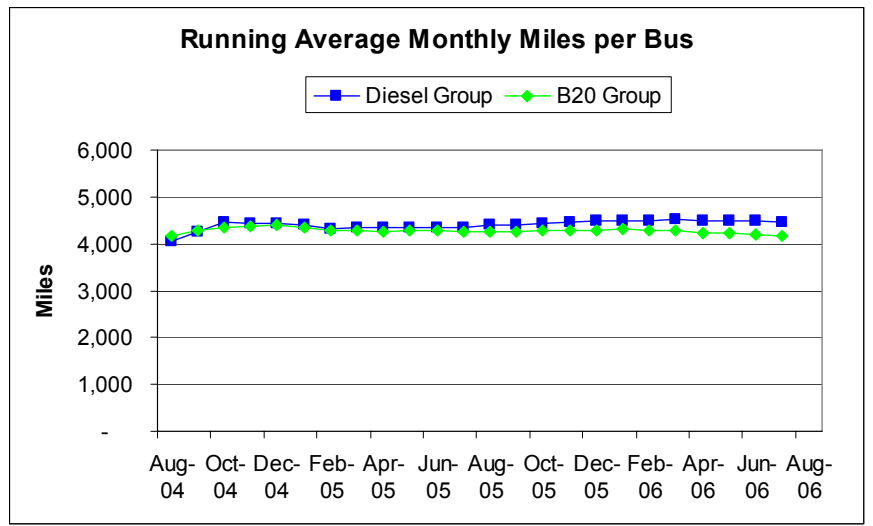

Figure 4. Running Average Monthly Miles

\section{FUEL ECONOMY}

Individual bus fuel economy over 24 months is shown in Table 4. Fuel economy values are calculated by dividing total miles driven by total gallons of fuel used. Buses are grouped by fuel type (B20 or diesel), and fuel economy results presented in Figure 5.

Although diesel bus 2205 exhibited a fuel economy consistently about $5 \%$ lower than the rest of the diesel baseline group, there is no apparent basis for removing it from this dataset as an outlier. As a result, there is no difference (4.41 mpg diesel vs. $4.41 \mathrm{mpg} \mathrm{B20}$ ) between the diesel and B20 study group fuel economies.

If diesel bus 2205 were removed as an outlier, the 24month average fuel economy for the diesel group becomes $4.46 \mathrm{mpg}$. In this case, the fuel economy for the B20 buses is $1.2 \%$ lower than that of the diesel buses $(p$-value $=0.02)$. A small fuel economy reduction is expected due to the lower energy content of B20 as compared to diesel fuel.

Table 4. Individual Bus Fuel Economy

\begin{tabular}{|c|c|}
\hline $\begin{array}{c}\text { Bus } \\
\text { Number }\end{array}$ & $\begin{array}{c}\text { Fuel Economy } \\
\text { (mpg) }\end{array}$ \\
\hline \multicolumn{2}{|c|}{ Diesel Group } \\
\hline 2203 & 4.46 \\
\hline 2204 & 4.46 \\
\hline 2205 & 4.25 \\
\hline 2206 & 4.46 \\
\hline Average & 4.41 \\
\hline \multicolumn{2}{|c|}{ B20 Group } \\
\hline 2207 & 4.37 \\
\hline 2208 & 4.40 \\
\hline 2209 & 4.41 \\
\hline 2210 & 4.45 \\
\hline 2211 & 4.41 \\
\hline Average & 4.41 \\
\hline
\end{tabular}




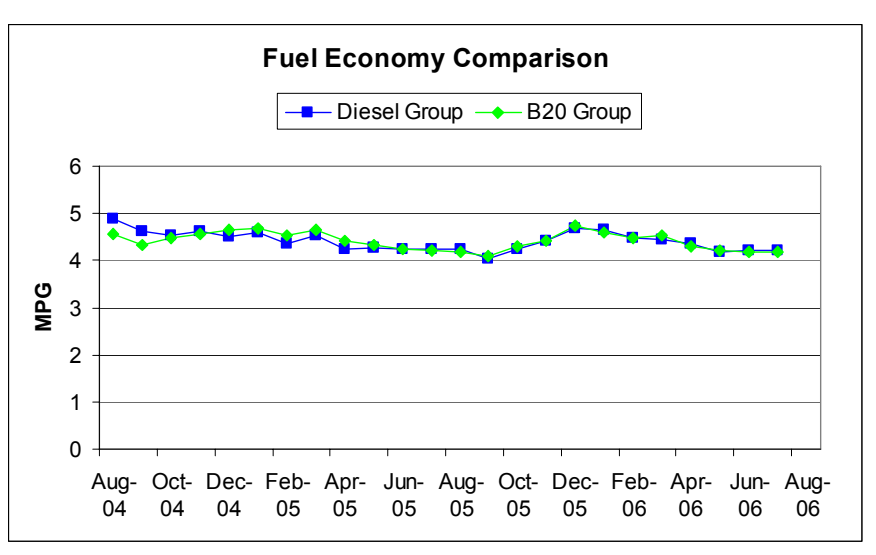

Figure 5. Fuel Economy Comparison by Fuel Group

\section{MAINTENANCE}

This analysis examines both total maintenance costs, as well as maintenance costs related to the engine and fuel system. Total maintenance costs include the costs of parts and labor, but do not include warranty costs (the five-year extended warranty expired in 2005). The labor rate for maintenance has been arbitrarily set at $\$ 50$ per hour and is not intended to reflect RTD's current labor mechanic rate. Cost per mile is calculated as follows:

\section{Cost per mile $=\left(\left(\right.\right.$ labor hours $\left.{ }^{*} \$ 50\right)+$ parts cost $) /$ mileage}

Bus maintenance costs over 24 months are presented in Table 5. The running average of maintenance costs for the diesel and B20 groups are compared in Figure 6. This running average or cumulative presentation of maintenance costs shows the average of the costs up to a given month and smoothes occasional monthly spikes in maintenance. The total maintenance cost per mile for the B20 group was $5.2 \%$ lower than for the diesel group ( $p$-value $=0.27)$. This difference will be explored in further discussion regarding maintenance cost breakdown by vehicle system.

Table 5. Bus Maintenance Costs

\begin{tabular}{|c|c|c|c|c|}
\hline $\begin{array}{c}\text { Bus } \\
\text { Number }\end{array}$ & $\begin{array}{c}\text { Miles } \\
\text { Driven }\end{array}$ & $\begin{array}{c}\text { Labor } \\
\text { Hours }\end{array}$ & $\begin{array}{c}\text { Parts } \\
\text { Cost }\end{array}$ & $\begin{array}{c}\text { Total Cost } \\
\text { (\$/mile) }\end{array}$ \\
\hline \multicolumn{5}{|c|}{ Diesel Group } \\
\hline 2203 & 105,499 & 892 & $\$ 11,965$ & $\$ 0.54$ \\
\hline 2204 & 106,788 & 835 & $\$ 14,254$ & $\$ 0.52$ \\
\hline 2205 & 110,133 & 965 & $\$ 14,178$ & $\$ 0.57$ \\
\hline 2206 & 105,981 & 852 & $\$ 13,555$ & $\$ 0.53$ \\
\hline Totals & $\mathbf{4 2 8 , 4 0 1}$ & $\mathbf{3 , 5 4 4}$ & $\mathbf{\$ 5 3 , 9 5 1}$ & $\mathbf{\$ 0 . 5 4}$ \\
\hline \multicolumn{5}{|c|}{ B20 Group } \\
\hline 2207 & 102,614 & 770 & $\$ 7,366$ & $\$ 0.45$ \\
\hline 2208 & 100,484 & 888 & $\$ 11,507$ & $\$ 0.56$ \\
\hline 2209 & 95,358 & 844 & $\$ 8,647$ & $\$ 0.53$ \\
\hline 2210 & 101,815 & 757 & $\$ 11,957$ & $\$ 0.49$ \\
\hline 2211 & 100,962 & 800 & $\$ 13,145$ & $\$ 0.53$ \\
\hline Totals & $\mathbf{5 0 1 , 2 3 3}$ & $\mathbf{4 , 0 5 9}$ & $\mathbf{\$ 5 2 , 6 2 2}$ & $\mathbf{0 . 5 1}$ \\
\hline
\end{tabular}

Running Total Maintenance Cost per Mile

$\rightarrow$ Diesel Group $\multimap-$ B20 Group

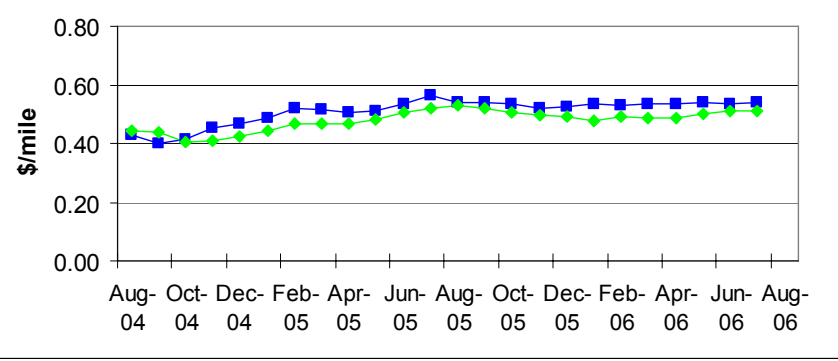

Figure 6. Running Total Maintenance Cost Comparison by Fuel Group

RTD codes and categorizes labor events and parts replacements according to vehicle subsystem or maintenance activity. For example, maintenance performed on the engine, fuel system, or as part of a preventative maintenance program is coded differently. Using these codes, the maintenance and repair data were analyzed in more detail to assess differences at the engine and fuel system level-the systems that B20 use might be expected to impact.

Bus maintenance costs over 24 months related to the engine and fuel system are presented in Table 6. The running average maintenance costs for the diesel and B20 groups are compared in Figure 7. The engine and fuel system maintenance cost per mile for the B20 group is $39 \%$ higher than for the diesel group ( $p$-value $=0.16$ ). Engine and fuel system maintenance costs are very similar for most of the test period. However, during the last 3 months of the study, average B20 maintenance costs increased due to component replacements on Bus 2211 in May and June of 2006 (details to follow). The $5.2 \%$ lower total maintenance cost per mile exhibited by the B20 group is not attributable to fewer engine and fuel system repairs. In calculation of the total maintenance costs, the higher engine and fuel system repair costs for the B20 group were offset by higher maintenance costs for transmission repairs in the diesel group (unrelated to fuel use).

Table 6. Bus Engine and Fuel System Maintenance Costs

\begin{tabular}{|c|c|c|c|c|}
\hline $\begin{array}{c}\text { Bus } \\
\text { Number }\end{array}$ & $\begin{array}{c}\text { Miles } \\
\text { Driven }\end{array}$ & $\begin{array}{c}\text { Labor } \\
\text { Hours }\end{array}$ & $\begin{array}{c}\text { Parts } \\
\text { Cost }\end{array}$ & $\begin{array}{c}\text { Total Cost } \\
\text { (\$/mile) }\end{array}$ \\
\hline \multicolumn{5}{|c|}{ Diesel Group } \\
\hline 2203 & 105,499 & 48 & $\$ 3,427$ & $\$ 0.06$ \\
\hline 2204 & 106,788 & 38 & $\$ 3,227$ & $\$ 0.05$ \\
\hline 2205 & 110,133 & 57 & $\$ 3,205$ & $\$ 0.05$ \\
\hline 2206 & 105,981 & 29 & $\$ 3,234$ & $\$ 0.04$ \\
\hline Totals & $\mathbf{4 2 8 , 4 0 1}$ & $\mathbf{1 7 1}$ & $\mathbf{\$ 1 3 , 0 9 3}$ & $\mathbf{\$ 0 . 0 5}$ \\
\hline \multicolumn{5}{|c|}{ B20 Group } \\
\hline 2207 & 102,614 & 25 & $\$ 2,910$ & $\$ 0.04$ \\
\hline 2208 & 100,484 & 81 & $\$ 3,402$ & $\$ 0.07$ \\
\hline 2209 & 95,358 & 80 & $\$ 3,474$ & $\$ 0.08$ \\
\hline 2210 & 101,815 & 27 & $\$ 4,104$ & $\$ 0.05$ \\
\hline 2211 & 100,962 & 70 & $\$ 7,118$ & $\$ 0.11$ \\
\hline Totals & $\mathbf{5 0 1 , 2 3 3}$ & $\mathbf{2 8 4}$ & $\mathbf{\$ 2 1 , 0 0 8}$ & $\$ \mathbf{0 . 0 7}$ \\
\hline
\end{tabular}




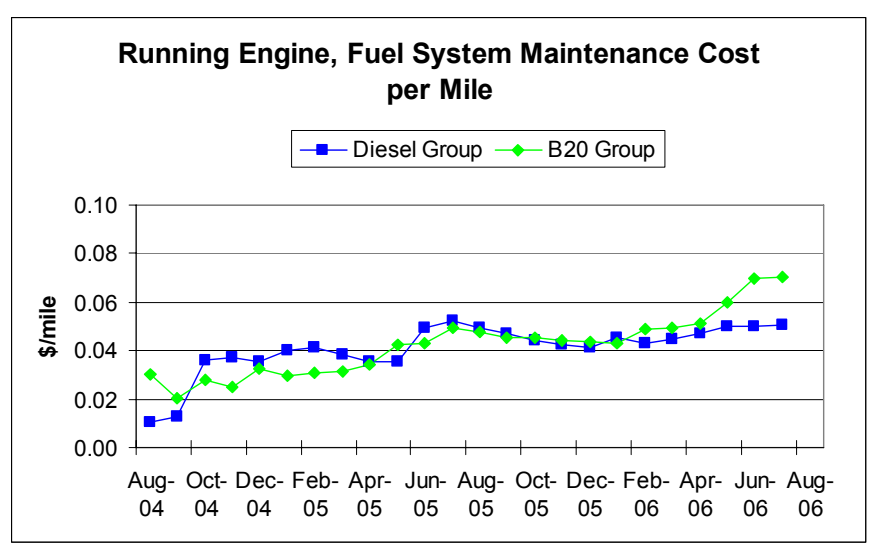

Figure 7. Running Engine and Fuel System Maintenance Cost Comparison by Fuel Group

Looking specifically at fuel system parts that may be considered potentially susceptible to B20 use, maintenance items found in the data included the following:

- Fuel pump

- Fuel pump gasket

- Fuel injector

- Fuel injector O-ring

- Fuel lines

- Fuel filter.

These parts are all categorized as fuel system parts, with the exception of the fuel filter. The fuel filter is grouped with a suite of preventative maintenance repair checks and part replacements. Preventative maintenance events are scheduled by RTD to occur every 6,000 miles of use.

The fuel system replacement parts installed during the study are shown in Table 7 for both diesel and B20 buses. During the evaluation period, fuel pumps were replaced for two diesel buses (2203 and 2206), and a fuel pump was replaced for a B20 bus (2209). A single fuel injector was replaced for one diesel bus (2205) and one B20 bus (2208). However, B20 Bus 2211 had all six injectors replaced due to a "no-start" condition in May 2006. In June 2006, Bus 2211 had a cylinder head replacement due to a "burnt valve" and all six injectors were again replaced as part of the rebuilt cylinder head replacement, although it does not appear that this second replacement of 6 valves was actually necessary. The labor and parts costs associated with the May June 2006 fuel injector and cylinder head replacements of Bus 2211 make up the difference in engine and fuel maintenance costs between the B20 and diesel groups in this study. Further analysis of the replaced parts is ongoing to determine if B20 use is related to their failure.

These results highlight certain challenges inherent in controlled fleet evaluations, and in particular the high variability in maintenance costs from vehicle to vehicle, independent of the fuel used. For this group of vehicles transmission repairs that were unrelated to fuel use caused the total maintenance costs for the diesel group to be higher. At the same time, a single maintenance event for Bus 2211 caused the running average engine and fuel system maintenance costs for the B20 group to spike during the last few months of the study. To mitigate the impact of the high variability in maintenance costs between vehicles, future studies will need to assess a larger fleet or a similar sized fleet for a significantly longer period of time.

Table 7. Replacement Fuel System Parts

\begin{tabular}{|c|c|c|c|c|}
\hline $\begin{array}{c}\text { Bus } \\
\text { Number }\end{array}$ & $\begin{array}{l}\text { Part } \\
\text { Description }\end{array}$ & $\begin{array}{c}\text { Date } \\
\text { Replaced }\end{array}$ & Quantity & $\begin{array}{l}\text { Total } \\
\text { Cost }\end{array}$ \\
\hline \multicolumn{5}{|c|}{ Diesel Group } \\
\hline 2203 & $\begin{array}{l}\text { Gasket Fuel } \\
\text { Pump }\end{array}$ & 07/13/05 & 1 & $\$ 4.81$ \\
\hline 2203 & $\begin{array}{l}\text { Gasket Fuel } \\
\text { Pump }\end{array}$ & $07 / 14 / 05$ & 1 & $\$ 4.91$ \\
\hline 2203 & Fuel Pump & $07 / 14 / 05$ & 1 & $\$ 622.67$ \\
\hline 2203 & $\begin{array}{l}\text { Tube Fuel } \\
\text { Supply }\end{array}$ & $01 / 24 / 05$ & 1 & $\$ 15.31$ \\
\hline 2204 & $\begin{array}{l}\text { Gasket Fuel } \\
\text { Pump }\end{array}$ & $07 / 15 / 05$ & 1 & $\$ 4.91$ \\
\hline 2205 & Fuel Injector & $01 / 27 / 06$ & 1 & $\$ 548.49$ \\
\hline 2206 & $\begin{array}{l}\text { Gasket Fuel } \\
\text { Pump }\end{array}$ & $10 / 21 / 04$ & 1 & $\$ 1.76$ \\
\hline 2206 & Fuel Pump & $10 / 21 / 04$ & 1 & $\$ 555.37$ \\
\hline 2206 & $\begin{array}{l}\text { Gasket Fuel } \\
\text { Pump }\end{array}$ & $02 / 20 / 06$ & 1 & $\$ 4.94$ \\
\hline & & & Total & $\$ 1,763$ \\
\hline \multicolumn{5}{|c|}{ B20 Group } \\
\hline 2208 & Fuel Injector & $07 / 08 / 05$ & 1 & $\$ 709.2$ \\
\hline 2208 & $\begin{array}{l}\text { Fuel } \\
\text { Solenoid } \\
\text { S/Off }\end{array}$ & $07 / 08 / 05$ & 1 & $\$ 36.47$ \\
\hline 2208 & Oring Injector & $07 / 11 / 05$ & 1 & $\$ 1.59$ \\
\hline 2208 & Oring Injector & $07 / 11 / 05$ & 1 & $\$ 1.61$ \\
\hline 2208 & Oring Injector & $07 / 11 / 05$ & 1 & $\$ 1.78$ \\
\hline 2209 & $\begin{array}{l}\text { Gasket Fuel } \\
\text { Pump }\end{array}$ & $10 / 26 / 04$ & 1 & $\$ 1.76$ \\
\hline 2209 & Fuel Pump & $10 / 26 / 04$ & 1 & $\$ 555.37$ \\
\hline 2209 & $\begin{array}{l}\text { Tube Fuel } \\
\text { Supply }\end{array}$ & $10 / 13 / 05$ & 1 & $\$ 15.82$ \\
\hline 2211 & Oring Injector & $05 / 24 / 06$ & 6 & $\$ 10.32$ \\
\hline 2211 & Fuel Injector & $05 / 24 / 06$ & 6 & $\$ 2,479.14$ \\
\hline 2211 & Fuel Injector & $06 / 14 / 06$ & 6 & $\$ 2,479.14$ \\
\hline & & & Total & $\$ 6,293$ \\
\hline
\end{tabular}

\section{ROAD CALLS}

A road call is defined as a call-in to dispatch reporting a mechanical problem. Depending on the nature of the problem, dispatch may instruct operators to continue driving their routes. However, a road call may stem from an issue that requires the bus to stop driving, allowing for roadside mechanical repair or towing back to the maintenance facility. Road calls and average miles (driven) between road calls (MBRC) are an important reliability indicator for the transit industry. For the purposes of this analysis, data received from RTD indicating the occurrence of a road call was recorded as such, regardless of its relative severity. 
Figure 8 shows the cumulative MBRC for all road calls for the B20 and diesel baseline groups. Average MBRC values over 24 months are 3,197 and 3,632 for diesel and B20 groups, respectively. The B20 buses are apparently $14 \%$ higher, but the difference is not significant ( $p$-value $=0.59$ ) and there is no evidence in the data to suggest this improvement is attributable to fuel use. Differences during the first months of the study are related to the variability of MBRC month-to-month, with a few months required for the running average of each group to settle. After 24 months of evaluation, there is no negative impact on MBRC from the use of B20.

However, in April 2005 two buses reported road calls for engine misfiring and stalling caused by plugged fuel filters. The first incident happened with Bus 2210 on April 8,2005 . The plugged fuel filter was removed from the vehicle and cut open for examination. A brown "greaselike" material was found in the filter pleats and was the suspected cause of the filter plugging (Figure 9).

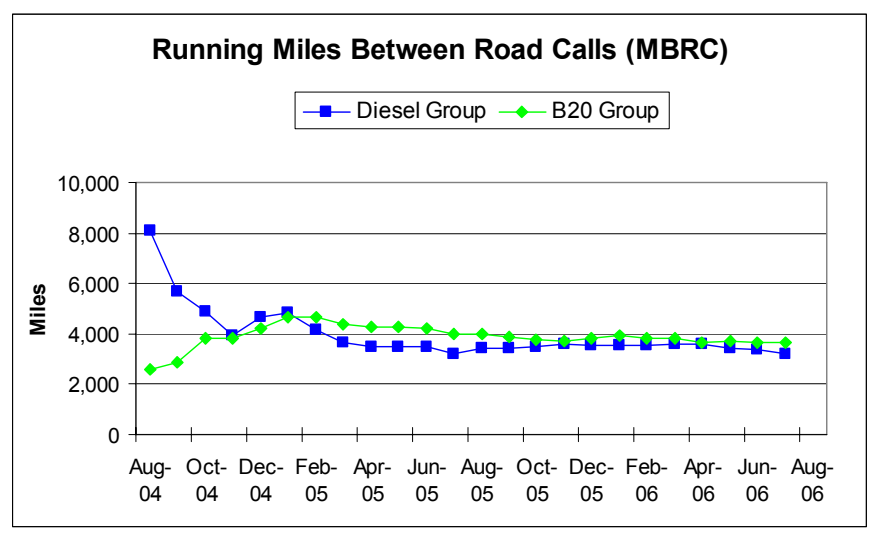

Figure 8. Running Average MBRC Comparison by Fuel Group

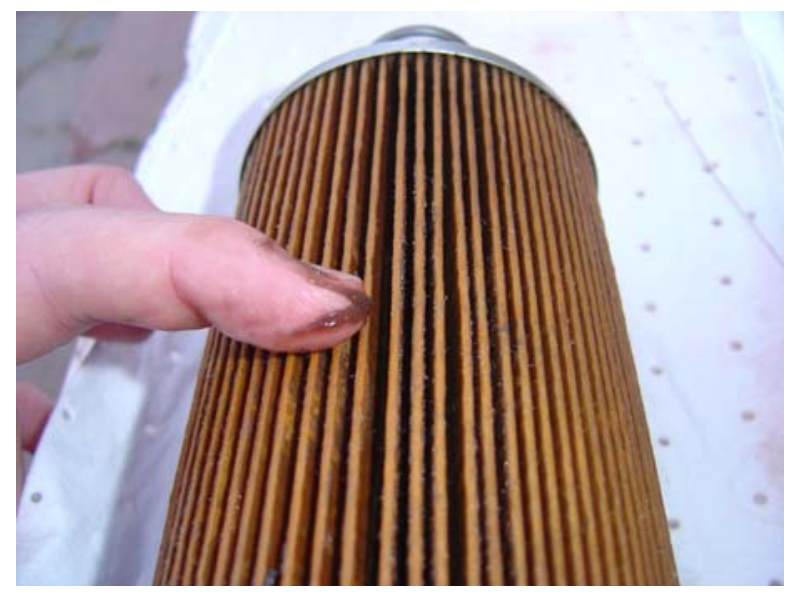

Figure 9. Bus 2210 Plugged Filter Examination

The second incident with Bus 2208 occurred three days later on April 11, 2005. The plugged filter from this bus also contained the brown material. The filters on the other three B20 buses were changed as a precautionary measure, and inspection of these used filters also revealed signs of the brown material, but not of the quantity and consistency of the plugged filters.
Fuel was removed from the vehicle fuel tanks and tested for several properties as shown in Table 8. None of the fuel samples exhibited excessively high levels of biodiesel or cold filter plugging point (CFPP, determined by ASTM D6371). Water determined by Karl Fischer method (ASTM D6304) indicated higher levels than typical of a No. 2 diesel fuel but not excessively high. The Bug Alert ${ }^{\mathrm{TM}}$ ATP test for microbial growth does not indicate that microbial contamination is an issue.

Table 8. Vehicle Fuel Testing Results (April 2005)

\begin{tabular}{|c|c|c|c|c|}
\hline Sample & $\begin{array}{c}\text { Percent } \\
\text { Biodiesel }\end{array}$ & $\begin{array}{c}\text { CFPP } \\
{ }^{\circ} \mathbf{C}\end{array}$ & $\begin{array}{c}\text { Water, } \\
\text { ppm }\end{array}$ & $\begin{array}{c}\text { Bug Alert } \\
\text { ATP }\end{array}$ \\
\hline 2207 & 18.4 & -24 & 72 & 139 (med) \\
\hline 2208 & 16.9 & -25 & 77 & 27 (low) \\
\hline 2209 & 19.2 & -25 & 88 & 57 (low) \\
\hline 2210 & 20.3 & -25 & 97 & 1 (very low) \\
\hline 2211 & 15.0 & -30 & 78 & 93 (low-med) \\
\hline
\end{tabular}

The dark brown gelatinous residue coating RTD fuel filter No. 2210 was analyzed by gas chromatography mass spectrometry (GC-MS) (Agilent $6890 \mathrm{GC}$ equipped with a 5890 MSD mass selective detector). The sample was prepared by scraping $23 \mathrm{mg}$ of residue from a filter pleat and dissolving this in $1.0 \mathrm{~mL}$ of toluene. $1.0 \mu \mathrm{L}$ of the solution was injected into the GC-MS using a split injection (100:1) onto a $30 \mathrm{~m} \times 0.25 \mathrm{~mm}$ column, $(0.50 \mu \mathrm{m}$ DB-5 film).

The resulting chromatographic data are shown as the total ion current (TIC) signal from the MSD, as a function of component elution time in Figure 10. The multiple peaks in the 8-17 minute region are identified as diesel hydrocarbons. The larger peaks in the 18-23 minute region are fatty acid methyl esters (FAME) from the soybean derived biodiesel. The presence of these components is due to the fact that no attempt was made to extract them from the sampled filter residue.

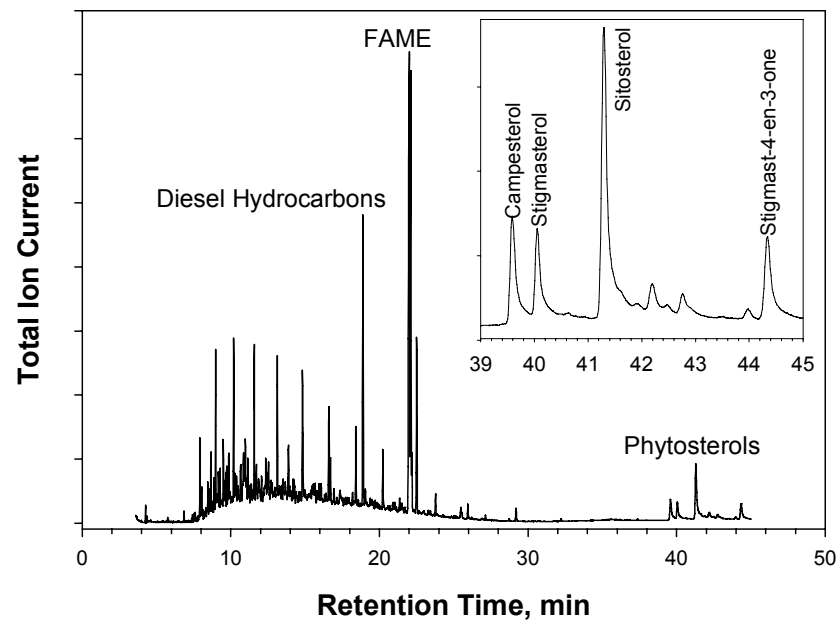

Figure 10. GC-MS results for brown material found on plugged fuel filter from Bus 2210

Plant (or phyto) sterols were detected in the 39-45 minute region. The compounds were identified by matching mass spectra of the peaks with library spectra. 
Campesterol, stigmasterol, sitosterol and stigmast-4-en3-one were the major species identified at retention times 39.59, 40.06, 41.30 and 44.34 minutes, respectively. The relative amounts are in rough agreement with those reported in soybean oil [10]. While this analysis is semi-quantitative, the total level of sterols is significantly higher than expected for B20. Thus, this analysis suggests that high levels of plant sterols might be responsible for the filter plugging. These sterols are much higher molecular weight ( $\geq 400 \mathrm{amu}$ ) and would have a higher freezing point than typical of FAME or diesel fuel components. However, based on this analysis alone we cannot rule out other potential causes.

Two other filter plugging events occurred during the remaining study period. One happened about two months later on June 14, 2005. Bus 2209 filled from the B20 dispenser with a report of slow fueling by the dispenser operator. The fuel filter on Bus 2209 plugged shortly thereafter. It was later discovered that the B20 tank was nearly empty. Bus 2209 required several fuel filter changes and vehicle tank drainage to correct the plugging problem. The remaining B20 was also drained from the storage tank, the tank cleaned, and then refilled for continued B20 service.

A final plugging event happened during the last month of the study period. Two buses, 2207 and 2211, were road called for plugged fuel filters on July 7,2006 . The fuel storage tank was again near empty in anticipation of completion of the study and removal of the tank. Because the tank is drawn from the bottom, this implies that a material less dense than biodiesel was floating on top and was pumped into the vehicles as the tank became nearly empty. One well known quality issue with biodiesel is the presence of soap, which in large enough concentration will float on top of a fuel tank.

As mentioned previously, fuel filters are not included in the analysis of engine and fuel system labor and parts costs because they are considered preventative maintenance. Due to fuel filter plugging events fuel filters were replaced on the B20 buses in excess of their preventative maintenance schedule. Table 9 lists the number of extra fuel filters replaced, and indicates the associated labor and parts cost. In addition, labor for diagnosis and related work (draining and refilling fuel tanks) amounted to $\$ 712.50$ for a total cost of $\$ 1,054.81$. These additional fuel filter replacements were not significant additions to the maintenance analysis, adding an additional maintenance cost per mile to the B20 group of only $\$ 0.002$. However, disruptions in transit service and related costs (bus substitution, affected ridership) are not captured in the maintenance costs, and were considered significant to RTD.
Table 9. Extra Fuel Filter Maintenance Costs

\begin{tabular}{|c|c|c|c|c|}
\hline $\begin{array}{c}\text { Bus } \\
\text { Number }\end{array}$ & $\begin{array}{c}\text { Extra } \\
\text { Fuel } \\
\text { Filters }\end{array}$ & $\begin{array}{c}\text { Labor } \\
\text { Hours }\end{array}$ & $\begin{array}{c}\text { Parts } \\
\text { Cost }\end{array}$ & $\begin{array}{c}\text { Total } \\
\text { Cost }\end{array}$ \\
\hline \multicolumn{5}{|c|}{ B20 Group } \\
\hline 2207 & 3 & 1 & $\$ 19.45$ & $\$ 69.45$ \\
\hline 2208 & 3 & 0.8 & $\$ 18.84$ & $\$ 58.84$ \\
\hline 2209 & 4 & 1 & $\$ 25.12$ & $\$ 75.12$ \\
\hline 2210 & 2 & 0.5 & $\$ 12.56$ & $\$ 37.56$ \\
\hline 2211 & 4 & 1.5 & $\$ 26.34$ & $\$ 101.34$ \\
\hline Totals & $\mathbf{1 6}$ & $\mathbf{4 . 8}$ & $\mathbf{\$ 1 0 2 . 3 1}$ & $\mathbf{\$ 3 4 2 . 3 1}$ \\
\hline
\end{tabular}

\section{FUEL TESTING}

Fuel delivery load samples were collected for analysis of biodiesel blend content. Fuel was delivered about twice a month with samples starting in September 2004. Biodiesel content was determined by infrared spectroscopy (FTIR). The fuel blender employed splash blending to mix biodiesel with petroleum diesel to make the required B20 blend. Biodiesel from a heated storage tank was loaded into the delivery truck and then driven to the fuel terminal where No. 2 diesel fuel (or both No. 2 and No. 1 diesel in the winter months) was typically bottom loaded to make the blend. From the terminal, the delivery truck would drive to the RTD Boulder facility and offload all of the B20 into the outdoor storage tank (typically 2,500 gallons per delivery). Load samples were taken from the top of the delivery truck tank at the terminal, prior to delivery.

In examining the delivery load samples for biodiesel content, blend levels were found to range from less than $1 \%$ to over $80 \%$ (Figure 11). After the discovery of erratic blend levels from the first group of samples tested in May 2005, the blender reported changing its blending procedure to include recirculation of fuel within the delivery truck tank prior to delivery. Later samples seemed consistently B20 for a short period then again became erratic.

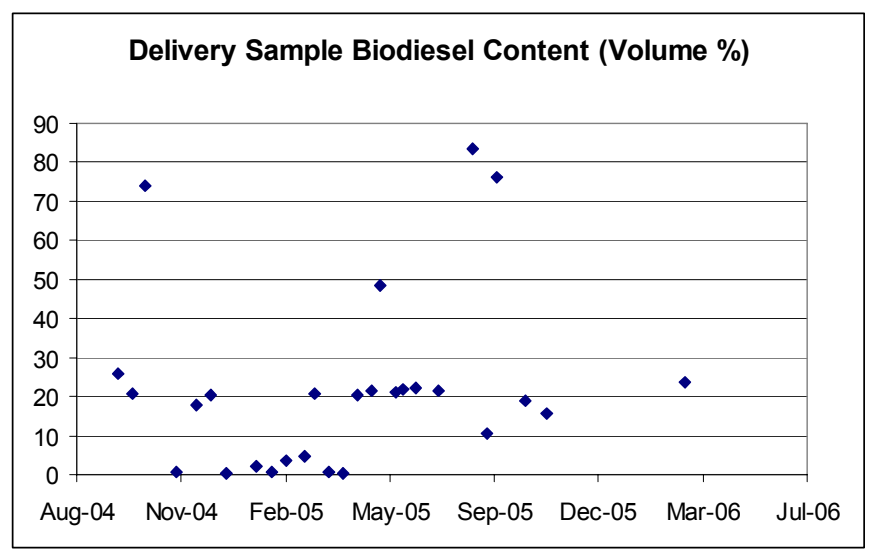

Figure 11. B100 Content of Delivery Load Samples

Inconsistent blend levels for B20 fuel are not uncommon. A survey of 50 B20 samples taken across the United States indicated varying blend levels and noted problems with splash blending [9]. In the RTD study however, all 
the fuel from each delivery truck was offloaded into the storage tank, and it appeared to have been completely blended in this process as evidenced by vehicle tank samples taken in April 2005 (Table 8) and March 2006 at or near B20 (Table 10).

In addition to blend level, several other properties were tested to examine fuel quality in March 2006. Acid value, peroxides, and aldehydes (or alkanals) were determined using the Saftest ${ }^{\mathrm{TM}}$ method. Acid and peroxides are consistently low in comparison to levels observed in the B20 quality survey [9]. Alkanals indicate some oxidative degradation of the biodiesel but are not high.

Table 10. B20 Vehicle Sample Testing March 2006

\begin{tabular}{|c|c|c|c|c|}
\hline $\begin{array}{l}\text { Vehicle } \\
\text { Number }\end{array}$ & $\begin{array}{c}\text { B100 } \\
\text { Content } \\
\text { Volume \% }\end{array}$ & $\begin{array}{c}\text { Acid } \\
\text { Value } \\
\mathrm{mgKOH} / \mathrm{g} \\
\end{array}$ & $\begin{array}{c}\text { Peroxide } \\
\text { Saftest } \\
\text { ppm } \\
\end{array}$ & $\begin{array}{l}\text { Aldehyde } \\
\text { Saftest } \\
\text { nmol/mL } \\
\end{array}$ \\
\hline 2207 & 20.3 & $<0.1$ & -- & 58.212 \\
\hline 2208 & 18.4 & $<0.1$ & 13.22 & 57.902 \\
\hline 2209 & 17.4 & $<0.1$ & 11.59 & 55.696 \\
\hline 2210 & 18.7 & $<0.1$ & 16.75 & 73.35 \\
\hline 2211 & 19.7 & $<0.1$ & 11.42 & 61.546 \\
\hline
\end{tabular}

Samples collected in March 2006 from both the diesel and biodiesel vehicle fuel tanks were combined to produce composite diesel and B20 samples. These were subjected to more detailed analysis as shown in Table 11. These results show the reduction of fuel sulfur content caused by blending in of biodiesel as well as the $2.4 \%$ reduction in energy content. The B20 blends exhibit significantly higher cetane number.

Table 11. Results of Testing of B20 and Diesel Composite samples Obtained from Vehicles March 2006

\begin{tabular}{|c|c|c|c|}
\hline \multicolumn{2}{|l|}{} & $\begin{array}{c}\text { B20 } \\
\text { Composite }\end{array}$ & $\begin{array}{c}\text { Diesel } \\
\text { Composite }\end{array}$ \\
\hline $\begin{array}{c}\text { Water \& } \\
\text { Sediment vol \% }\end{array}$ & D2709 & 0.01 & 0.01 \\
\hline Cloud Point $^{\circ} \mathrm{C}$ & $\mathrm{D} 2500$ & -13 & -14 \\
\hline Sulfur ppm & $\mathrm{D} 5453$ & & 324.1 \\
\hline Sulfur ppm & $\mathrm{D} 2622$ & 272 & \\
\hline Aromatics vol \% & $\mathrm{D} 1319$ & & 25.6 \\
\hline Olefins vol \% & & & 1.3 \\
\hline Saturates vol \% & & & 73.1 \\
\hline C mass\% & D5291 & 84.71 & 86.6 \\
\hline H mass\% & & 12.88 & 13.21 \\
\hline $\begin{array}{c}\text { Derived Cetane } \\
\text { Number }\end{array}$ & D6890 & 51.0 & 47.9 \\
\hline LHV BTU/lb & D240 & 17859.7 & 18306.6 \\
\hline
\end{tabular}

\section{OIL TESTING}

Oil was sampled from several of the test vehicles during oil drain intervals in March through June of 2006 and at the mileage indicated in Table 12. These data provide a snapshot of oil performance for the two fuels in terms of ZDDP (zinc dialkyldithiophosphate) decay, TBN (total base number) decay, oxidation, fuel dilution, viscosity, soot loading, and wear metals).

ZDDP decay and lubricant oxidation were assessed using FTIR. For ZDDP the strengths of the C-O-P stretching band at $957 \mathrm{~cm}^{-1}$ and of the $\mathrm{P}=\mathrm{S}$ stretching band at $670 \mathrm{~cm}^{-1}$ were measured. The decay of these bands with mileage for all samples listed in Table 12 is shown in Figure 12. This indicates exponential decay with mileage:

$$
\begin{aligned}
& C=C_{0} \exp (-\alpha m) \\
& \ln \left(1+\left(C-C_{0}\right) / C_{0}\right)=-\alpha m
\end{aligned}
$$

Where $\mathrm{m}=$ mileage

$\mathrm{C}_{0}=$ initial intensity

$\mathrm{C}=$ intensity at mileage $\mathrm{m}$

$\alpha=$ exponential decay constant

Table 12. Oil Samples Taken for Analysis, Miles Indicate Mileage Since Last Oil Change

\begin{tabular}{|c|c|c|}
\hline Vehicle No. & Sample Date & Miles \\
\hline \multicolumn{3}{|c|}{ Diesel Group } \\
\hline 2203 & $3 / 14 / 06$ & 1295 \\
\hline 2203 & $4 / 26 / 06$ & 7770 \\
\hline 2203 & $6 / 8 / 06$ & 5375 \\
\hline 2204 & $3 / 14 / 06$ & 1392 \\
\hline 2204 & $4 / 22 / 06$ & 6850 \\
\hline 2204 & $6 / 6 / 06$ & 6035 \\
\hline 2205 & $5 / 17 / 06$ & 7463 \\
\hline 2206 & $6 / 1 / 06$ & 5840 \\
\hline \multicolumn{3}{|c|}{ B20 Group } \\
\hline 2207 & $3 / 14 / 06$ & 2900 \\
\hline 2207 & $6 / 6 / 06$ & 7256 \\
\hline 2208 & $3 / 14 / 06$ & 1834 \\
\hline 2208 & $4 / 25 / 06$ & 7314 \\
\hline 2209 & $4 / 25 / 06$ & 802 \\
\hline 2210 & $4 / 29 / 06$ & 3634 \\
\hline 2211 & $5 / 24 / 06$ & 8800 \\
\hline
\end{tabular}

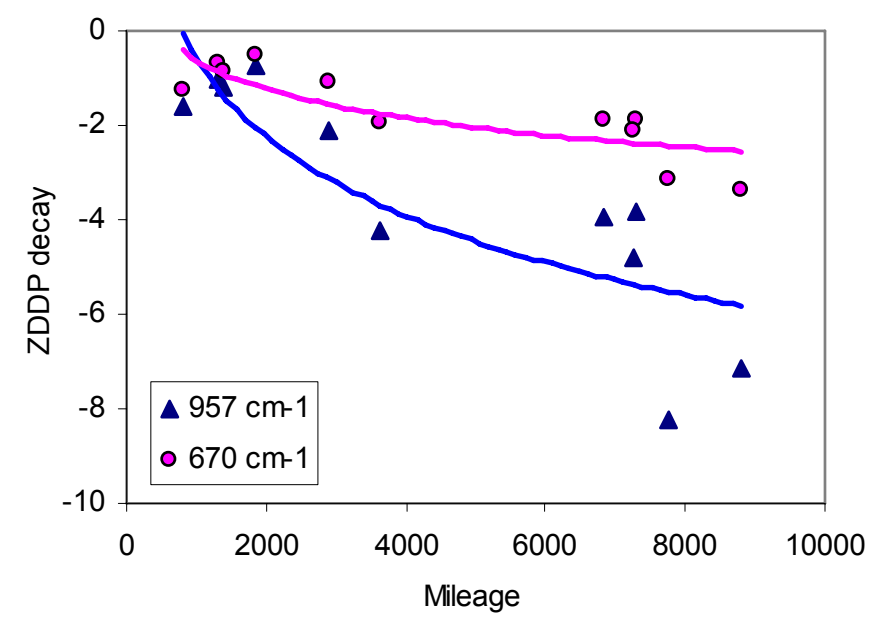

Figure 12. ZDDP Decay in Lubricants from All Vehicles. C-O-P Monitored at $957 \mathrm{~cm}^{-1}$ and $\mathrm{P}=\mathrm{S}$ Monitored at $670 \mathrm{~cm}^{-1}$ 
Fitting of the data to equation 2 (Figure 13) yields exponential decay constants of $0.00007 /$ mile for the C-O$P$ stretch and $0.0001 / \mathrm{mile}$ for the $P=S$ stretch, which are consistent with previous testing at Cummins and with expectations for oil decay for this engine. Differences between the fuels for ZDDP decay were small and probably not significant. The buildup of oxidation products was monitored via the acid carbonyl IR band at $1700 \mathrm{~cm}^{-1}$. Oxidation products grow exponentially with mileage as shown in Figure 14. Lubricants contain overbased detergent, which neutralize acids by formation of carboxylate. The formation of carboxylate was also monitored via the IR band at $1640 \mathrm{~cm}^{-1}$ which also shows exponential growth. As seen in Figure 14, both acid and carboxylate growth has essentially the same slope or exponential growth constant. This indicates that the acids being formed are being adequately neutralized by the detergent. No difference was observed between diesel and B20.

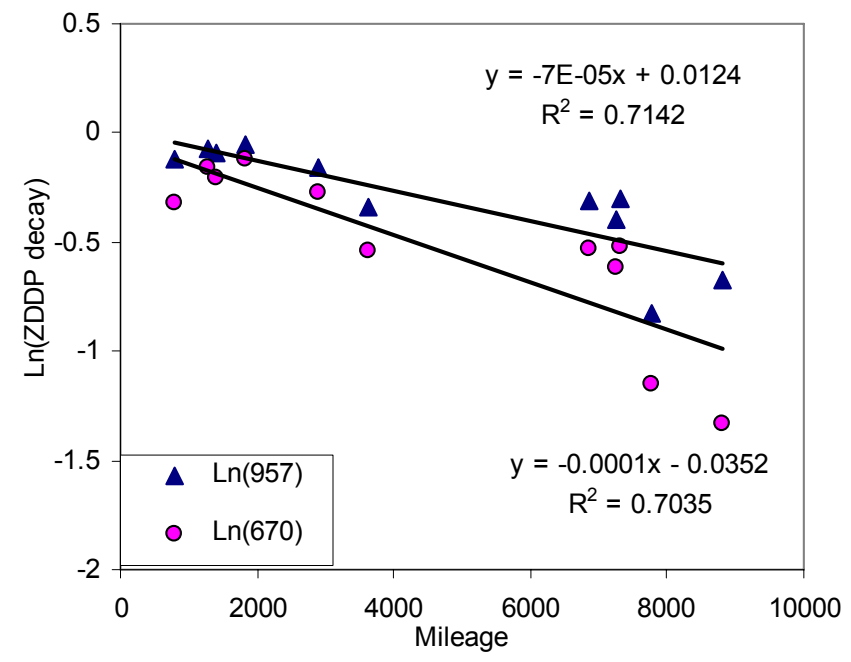

Figure 13. Results of Fitting ZDDP Decay Data to Linearized Exponential Law, Equation 2

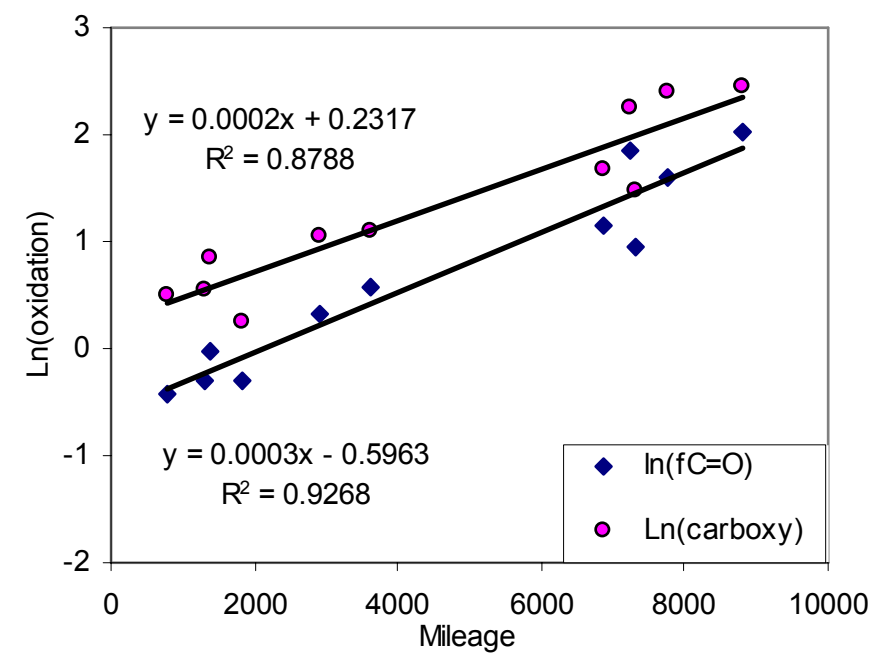

Figure 14. Results of Fitting Acid Carbonyl and Carboxylate Growth Data to Linearized Exponential Law, Equation 2
TBN also decays exponentially with mileage, as shown in Figure 15. The decay constant is consistent with Cummins experience for conventional diesel fuel. TBN is a sensitive function of fuel sulfur content. As noted, biodiesel dilutes the sulfur content of the diesel fuel. Table 13 lists TBN values and other oil properties as a function of mileage. Examination of these values suggests that TBN decay is occurring more slowly for the B20 blends; however, this cannot be proven based on this limited dataset.

Fuel dilution of the lubricant was examined by a gas chromatography method for some samples. This method yields the amount of petroleum diesel fuel in the lubricant and results are shown in Table 13. Fuel dilution by lubricant is low in all cases, and even lower for the B20 blends. Additionally, lubricant dilution by methyl ester from the biodiesel fuel blend was examined by FTIR. No ester was detected in the lubricant from the B20 buses except for the 7314 mile sample from bus 2208, which contained $0.6 \%$ methyl ester.

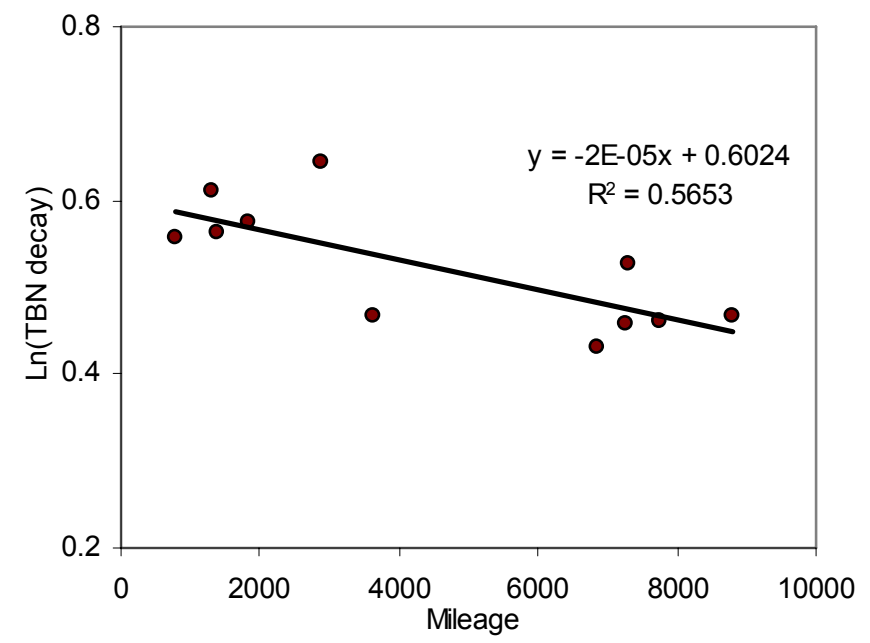

Figure 15. Results of Fitting TBN Decay Data to Linearized Exponential Law, Equation 2

Metals analysis was performed by ICP-AA (inductively coupled plasma/atomic absorption). Calcium, zinc, and phosphorus increase in concentration as the lubricant is consumed by evaporation, thus can be used to track oil consumption. However for these oil samples the concentrations of these metals do not exhibit any trend with mileage and show no discernable difference for diesel and B20. Iron, copper, and chromium are indicators of engine wear. There is no discernable different for oil samples from the diesel and B20 buses. Finally, sodium levels are low in all cases indicating no coolant leak or contamination with high soap content biodiesel.

Soot in oil was determined by a thermogravimetric analysis method, and these values are also shown in Table 13. Soot levels are low in all cases but about $50 \%$ lower on average in the B20 lubricant samples. This lower soot loading for B20 is a significant potential advantage that should be examined in more detail in 
Table 13. Lubricant Properties at Various Mileage

\begin{tabular}{|c|c|c|c|c|c|c|c|c|c|c|c|}
\hline Vehicle No. & Miles & TBN & $\begin{array}{l}\text { Fuel } \% \\
\text { by GC }\end{array}$ & $\begin{array}{c}\mathrm{Ca}, \\
\mathrm{ppm}\end{array}$ & $\begin{array}{l}\mathrm{Zn}, \\
\mathrm{ppm}\end{array}$ & $\begin{array}{c}\mathrm{P}, \\
\mathrm{ppm}\end{array}$ & $\begin{array}{c}\text { Fe, } \\
\text { ppm }\end{array}$ & $\begin{array}{c}\mathrm{Cu}, \\
\mathrm{ppm}\end{array}$ & $\begin{array}{c}\mathrm{Cr}, \\
\mathrm{ppm}\end{array}$ & $\begin{array}{c}\mathrm{Na}, \\
\mathrm{ppm}\end{array}$ & $\begin{array}{l}\text { Soot, } \\
\text { wt } \%\end{array}$ \\
\hline Unused Oil & 0 & 9.27 & 0 & 3261 & 1246 & 1215 & 2 & 0 & 0 & 0 & 0 \\
\hline \multicolumn{12}{|c|}{ Diesel Group } \\
\hline 2203 & 1295 & 8.4 & 0.70 & 3265 & 1265 & 1177 & 5 & 0 & 0 & 1 & -- \\
\hline 2203 & 5375 & 4.21 & -- & 3213 & 1259 & 1111 & 24 & 1 & 1 & 3 & 3.83 \\
\hline 2203 & 7770 & 5.86 & -- & 3421 & 1323 & 1173 & 21 & 1 & 2 & 4 & 3.09 \\
\hline 2204 & 1392 & 7.57 & 0.70 & 3411 & 1312 & 1234 & 7 & 6 & 1 & 2 & -- \\
\hline 2204 & 6035 & 4.64 & -- & 3385 & 1299 & 1178 & 22 & 3 & 3 & 3 & 4.16 \\
\hline 2204 & 6850 & 5.37 & 0.30 & 3731 & 1401 & 1255 & 23 & 10 & 3 & 4 & 3.42 \\
\hline 2205 & 7463 & 4.7 & -- & 3399 & 1297 & 1168 & 20 & 1 & 1 & 4 & 3.9 \\
\hline 2206 & 5840 & 4.73 & -- & 3293 & 1311 & 1171 & 25 & 1 & 2 & 4 & 4.27 \\
\hline \multicolumn{12}{|c|}{ B20 Group } \\
\hline 2207 & 2900 & 7.75 & 0 & 3684 & 1286 & 1210 & 6 & 2 & 3 & 3 & -- \\
\hline 2207 & 7256 & 5.82 & -- & 3213 & 1268 & 1144 & 13 & 3 & 5 & 3 & 1.9 \\
\hline 2208 & 1834 & 9.03 & 0.20 & 3508 & 1258 & 1208 & 3 & 0 & 0 & 1 & -- \\
\hline 2208 & 7314 & 6.95 & 0 & 3802 & 1413 & 1277 & 13 & 1 & 1 & 6 & 1.75 \\
\hline 2209 & 802 & 7.47 & -- & 3405 & 1295 & 1237 & 4 & 0 & 0 & 1 & 0.32 \\
\hline 2210 & 3634 & 5.93 & -- & 3367 & 1327 & 1179 & 20 & 2 & 2 & 4 & 3.72 \\
\hline 2211 & 8800 & 5.93 & -- & 3330 & 1319 & 1181 & 20 & 1 & 1 & 4 & 2.53 \\
\hline
\end{tabular}

lubricant performance tests. The lubricant samples were also tested for viscosity and viscosity index. These values did not decay significantly during the oil drain interval for lubricant from either group of vehicles.

Overall the lubricant analysis indicates no negative impact from the use of B20 and suggests some potential benefits. To quantify these potential benefits will require additional study.

\section{CHASSIS EMISSION TESTS}

Emission testing was conducted on two vehicles: bus numbers 2208 and 2211. The buses were tested using both the in-use No. 2 diesel and the in-use B20 fuels. Properties of these fuels are listed in Table 14. At the time of this testing, the B20 was being blended with the same diesel fuel used by the diesel buses. The B20 shows significantly higher cetane number, in part because of the relatively high cetane number of biodiesel which is typically 54 [9], but this can only account for a cetane number increase of about 3 . The additional increase is caused by the multifunctional diesel additive used by the biodiesel supplier, which includes a cetane improving additive. The aromatic content of the B20 appears to be slightly higher than the aromatic content of the diesel fuel; however biodiesel is known to interfere in method D1319 [11] and may provide falsely high values for B20 blends. Two drivers were used to perform the test cycles. Testing was performed so that each driver performed the same number of test runs on each bus, per fuel.

Six to eight total repeated test cycle runs were driven for each bus on each fuel, results for each test run are reported in Appendix A; and summary results analyzed statistically for each bus and for both buses combined are reported in Table 15. The data show that for these vehicles on this test cycle, operation on B20 reduced all regulated pollutants, including $\mathrm{NO}_{\mathrm{x}}$. Fuel economy on a $\mathrm{mpg}$ basis was decreased by roughly $2 \%$, in agreement with the lower energy content of B20. In most cases $p<0.05$, indicating changes are significant with $95 \%$ or better confidence.

Table 14. Fuel Properties of Fuel Used for Emissions Testing

\begin{tabular}{|c|c|c|}
\hline & B20 & Diesel \\
\hline B100 Content (Vol \%) & 21.1 & NA \\
\hline Distillation T90, ${ }^{\circ} \mathrm{F}$ (D86) & 644.4 & 617.4 \\
\hline Flash Point, ${ }^{\circ} \mathrm{F}$ (D93) & 159 & 151 \\
\hline Copper Corrosion (D130) & $1 \mathrm{a}$ & $1 \mathrm{a}$ \\
\hline $\begin{array}{l}\text { Kinematic Viscosity, cSt@ } 40^{\circ} \mathrm{C} \\
\text { (D445) }\end{array}$ & 2.726 & 2.438 \\
\hline Ash, \%Mass (D482) & 0 & 0 \\
\hline Carbon Residue, \%mass (D524) & $<0.010$ & 0.04 \\
\hline Cetane Number (D613) & 47 & 40 \\
\hline Cloud Point, ${ }^{\circ} \mathrm{F}$ (D5773) & 6 & 0 \\
\hline Total Sulfur, ppm (D5453) & 280 & 364 \\
\hline $\begin{array}{l}\text { Water \& Sediment, \%Vol } \\
\text { (D2709) }\end{array}$ & 0 & 0 \\
\hline Aromatics, \%Vol (D1319) & 28.5 & 27.1 \\
\hline $\begin{array}{l}\text { Heat of Combustion, BTU/gal } \\
\text { (D240) }\end{array}$ & 134,650 & 137,720 \\
\hline $\begin{array}{l}\text { Acid Number, mg KOH/gram } \\
\text { (D664) }\end{array}$ & 0.16 & 0.01 \\
\hline Peroxide Number, ppm (D3703) & 8.1 & 0 \\
\hline
\end{tabular}

Clearly the oxygen content provided by the biodiesel is primarily responsible for the reductions in $\mathrm{THC}, \mathrm{CO}$, and $\mathrm{PM}$; in agreement with previous studies [1]. The situation for $\mathrm{NO}_{\mathrm{x}}$ emissions is less clear. B20 exhibited a cetane 
number of 47 versus 40 for the in-use diesel fuel. For fuels that are otherwise identical, increasing cetane number from 40 to 47 could produce a $\mathrm{NO}_{x}$ reduction of $3 \%$ [12]. However, in testing of a third mechanically identical transit bus where neither fuel contained additives we have observed $\mathrm{NO}_{x}$ reductions ranging from 2 to $5 \%$ [13]. Thus it seems unlikely that additive effects are the main cause of the $\mathrm{NO}_{\mathrm{x}}$ reduction observed here.

By testing two buses, with two drivers each, on both fuels, some information regarding variability between vehicles and between drivers can also be acquired. This analysis can be useful to evaluate whether the results can be interpreted to likely apply generally to the Skip bus fleet or if vehicle-to-vehicle variability prevents such a generalized conclusion.

The data show good agreement between the two test vehicles, with no statistically significant difference (at alpha of 0.05), between the two buses for any of the regulated emissions. There was a statistically significant difference between the two buses for fuel economy with bus 2211 achieving approximately $3 \%$ better fuel economy than bus 2208 , on average.

There was no statistically significant difference between drivers (alpha of 0.05) for $\mathrm{NO}_{x}$ emissions, THC emissions, or fuel economy. There was a statistically significant difference between drivers for $\mathrm{CO}$ and $\mathrm{PM}$ emissions, with these emissions from driver $A$ averaging about 22\%-23\% higher than driver B.

Table 15. Summary Results for Bus Emission Testing

\begin{tabular}{|l|c|c|c|c|c|}
\hline Bus & $\begin{array}{c}\mathbf{N O}_{\mathbf{x}} \\
\text { g/mile }\end{array}$ & $\begin{array}{c}\text { THC } \\
\text { g/mile }\end{array}$ & $\begin{array}{c}\text { CO } \\
\text { g/mile }\end{array}$ & $\begin{array}{c}\text { PM } \\
\text { g/mile }\end{array}$ & $\begin{array}{c}\text { FE } \\
\mathbf{m p g}\end{array}$ \\
\hline 2211 & \multicolumn{5}{|c|}{} \\
\hline Base & 19.81 & 0.871 & 3.60 & 0.274 & 4.70 \\
\hline B20 & 18.65 & 0.625 & 2.63 & 0.226 & 4.59 \\
\hline$\% \Delta$ & -5.8 & -28.2 & -26.8 & -17.3 & -2.4 \\
\hline p-value & $<0.001$ & 0.001 & $<0.001$ & 0.042 & 0.032 \\
\hline 2208 & \multicolumn{7}{|l|}{} \\
\hline Base & 19.44 & 0.807 & 3.44 & 0.2648 & 4.60 \\
\hline B20 & 18.67 & 0.571 & 2.73 & 0.2150 & 4.45 \\
\hline$\% \Delta$ & -3.9 & -28.0 & -20.3 & -19.9 & -2.1 \\
\hline p-value & 0.039 & 0.002 & 0.071 & 0.153 & 0.018 \\
\hline
\end{tabular}

\section{CONCLUSIONS}

In the 100,000-mile evaluation of transit buses operated on B20, the following operational differences were found related to vehicle fuel:

- The fuel economy for both petroleum diesel and B20 groups was $4.41 \mathrm{mpg}$ based on in-use fleet data. An approximately $2 \%$ reduction in fuel economy for B20 was measured in laboratory emission testing.

- Total maintenance costs per mile were $\$ 0.54$ for the diesel group and $\$ 0.51$ for the B20 group, and maintenance costs specific to the engine and fuel systems were $\$ 0.05$ and $\$ 0.07$ per mile, respectively. Because of high variability in maintenance costs between vehicles, the engine and fuel system maintenance costs for the two groups are not significantly different with a high degree of confidence ( $p$ 0.5). The increased engine and fuel system costs for the B20 group were due to fuel injector and cylinder head replacements on Bus 2211. Further study will be required to determine if B20 fuel use caused these failures.

- Miles between road calls averaged 3,197 for the diesel group and 3,632 for the B20 group. There is no evidence in the data to suggest this difference is related to fuel use.

- Fuel filter plugging on the B20 buses caused road calls, and required extra filter replacements in the B20 group. Although the additional maintenance cost was small, adding only $\$ 1,054.81$ to the B20 group or $\$ 0.002$ per mile, the events were significant to the transit district because of resulting disruptions to normal bus service. Fuel filter plugging may have been caused by the presence of high levels of plant sterols in the biodiesel or other fuel quality issues.

- Measurement of biodiesel blend level showed erratic biodiesel content for delivery load samples. Vehicle samples, however, were consistently at or near B20 indicating complete blending had occurred during delivery and offloading of the fuel.

- Oil analysis results indicate no additional wear metals from the use of $B 20$, with similar rates of TBN and ZDDP decay, oxidation, fuel dilution, and viscosity. Soot levels in the lubricant were significantly lower for the B20 vehicles. Quantifying potential benefits will require additional study.

- Laboratory chassis testing on the CSHVC cycle using the in-use fuels found that B20 reduced emissions of all regulated pollutants and caused a small fuel economy decrease.

\section{ACKNOWLEDGMENTS}

The FreedomCAR and Vehicle Technologies Program, Fuels Technologies Subprogram of the U.S. Department of Energy sponsored NREL's participation in this project.

The authors thank the Technical Services group and the Boulder maintenance staff of RTD. Special thanks are extended to Dean Shaklee from Operations; Dave Richardson and Dave Ober from Maintenance Reporting Systems; and Hugh Willis and Ray Fernandez from Boulder Maintenance. Additionally the authors wish to thank Dave Forrester of Power Service Products for B20 testing during the fuel filter plugging incident; Dale Rains of Gray Oil; and Sean Lafferty and Ryan Lafferty of Blue Sun Biodiesel. 


\section{REFERENCES}

1. United States Environmental Protection Agency. "A Comprehensive Analysis of Biodiesel Impacts on Exhaust Emissions." Draft Technical Report, EPA420-P-02-001, 2002.

2. Sheehan J., Camobreco V., Duffield J., Graboski M., Shapouri H. "An Overview of Biodiesel and Petroleum Diesel Life Cycles." National Renewable Energy Laboratory, NREL/TP-580-24772, May 1998.

3. Graboski M., McCormick R. "Combustion of Fat and Vegetable Oil Derived Fuels in Diesel Engines." Prog. Energy Combust. Sci.; Vol. 24, 1998; p. 125164.

4. Bickel K., Strebig K. "Soy-Based Diesel Fuel Study." Final report to Legislative Commission on Minnesota Resources and Minnesota Soygrowers Association, 2000.

5. Chase C.L., Peterson C.L., Lowe G.A., Mann P., Smith J.A., Kado N.Y. "A 322,000 Kilometer (200,000 Mile) Over the Road Test with HySEE Biodiesel in a Heavy Duty Truck." SAE Technical Paper No. 2000-01-2647, 2000.

6. Biodiesel Demonstration and Assessment with the Société de Transport de Montréal (STM), Final Report http://www.stm.info/English/info/a-biobusfinal.pdf, May 2003.

7. Fraer R., Dinh H., Proc K., McCormick R.L., Chandler K., Buchholz B. "Operating Experience and Teardown Analysis for Engines Operated on Biodiesel Blends (B20)." SAE Technical Paper No. 2005-01-3641, 2005.

8. Dtn Energy's Alternative Fuels Index; Vol. 4, Issue 32, 2006; p. 2.

9. McCormick R.L., Alleman T.L., Ratcliff M., Moens L., Lawrence R. "Survey of the Quality and Stability of Biodiesel and Biodiesel Blends in the United States in 2004." National Renewable Energy Laboratory, NREL/TP-540-38836, October 2005.

10. Tarandjiiska, R.B., Marekov, I.N., NikolovaDamyanova, B.M., Amidzhin, B.S. "Determination of Triacylglycerol Classes and Molecular Species in Seed Oils with High Content of Linoleic and Linolenic Fatty Acids" J. of the Sci. of Food and Agriculture; Vol. 24, 1996 p. 403-410.

11. Active Standard: D1319-03e1 "Standard Test Method for Hydrocarbon Types in Liquid Petroleum Products by Fluorescent Indicator Adsorption", ASTM International, West Conshohocken, PA; www.astm.org.

12. United States Environmental Protection Agency. "The Effect of Cetane Number Increase Due to Additives on $\mathrm{NO}_{x}$ Emissions from Heavy-Duty Highway Engines", Final Technical Report, EPA420R-03-002, February 2003.

13. McCormick, R.L., Hayes, R.R., Williams, A., Ireland, J. "Effect of Biodiesel Blends on Vehicle Emissions", Milestone Report. National Renewable Energy Laboratory, NREL/MP-540-40554, October 2006.

\section{CONTACT}

Ken Proc can be contacted at kenneth_proc@nrel.gov.

\section{DEFINITIONS, ACRONYMS, ABBREVIATIONS}

AA: Atomic absorption

ASTM: ASTM International

B20: A blend of $20 \%$ biodiesel with diesel fuel

CFPP: Cold filter plugging point

CFR: Code of Federal Regulations

CSHVC: City-suburban heavy-vehicle cycle

CO: Carbon monoxide

$\mathrm{CO}_{2}: \quad$ Carbon dioxide

DC: Direct current

FAME: Fatty acid methyl esters

FE: $\quad$ Fuel economy

FTIR: Infrared spectroscopy

GCMS: Gas chromatography mass spectrometry

ICP: Inductively coupled plasma

MBRC: Miles between road calls

$\mathbf{N O}_{\mathbf{x}}: \quad$ Oxides of nitrogen

NREL: National Renewable Energy Laboratory

PM: Particulate matter

RC: $\quad$ Road call

RTD: Regional Transportation District

TBN: Total base number

THC: Total hydrocarbon

VIN: Vehicle identification number

ZDDP: Zinc dialkyldithiophosphate 
Table A1. Chassis Emissions Test Data

\begin{tabular}{|c|c|c|c|c|c|c|c|}
\hline \multirow[t]{7}{*}{ Bus 2211} & Fuel & Run & $\begin{array}{c}\text { NOx } \\
\text { g/mile }\end{array}$ & $\begin{array}{c}\text { THC } \\
\text { g/mile }\end{array}$ & $\begin{array}{c}\text { CO } \\
\text { g/mile }\end{array}$ & $\begin{array}{c}\text { PM } \\
\text { g/mile }\end{array}$ & $\begin{array}{c}\text { Fuel } \\
\text { Economy } \\
\text { mpg }\end{array}$ \\
\hline & Base & 332 & 19.90 & 0.906 & 4.18 & 0.2380 & 4.68 \\
\hline & Base & 333 & 20.56 & 1.033 & 3.74 & 0.2185 & 4.70 \\
\hline & Base & 337 & 19.69 & 0.816 & 3.48 & 0.3055 & $\mathrm{~nm}$ \\
\hline & Base & 338 & 19.81 & 0.854 & 3.08 & 0.2616 & 4.68 \\
\hline & Base & 339 & 19.33 & 0.789 & 3.78 & 0.3263 & 4.67 \\
\hline & Base & 340 & 19.54 & 0.829 & 3.32 & 0.2940 & 4.77 \\
\hline \multicolumn{3}{|l|}{ Average } & 19.80 & 0.871 & 3.60 & 0.2740 & 4.70 \\
\hline \multicolumn{3}{|c|}{ Standard deviation } & 0.42 & 0.09 & 0.39 & 0.04 & 0.04 \\
\hline \multicolumn{3}{|c|}{ Coefficient of variation } & $2.1 \%$ & $10.2 \%$ & $10.8 \%$ & $15.2 \%$ & $0.9 \%$ \\
\hline & B20 & 326 & 18.78 & 0.604 & 2.48 & 0.2421 & $\mathrm{~nm}$ \\
\hline & $\mathrm{B} 20$ & 328 & 18.54 & 0.598 & 2.94 & 0.2200 & 4.54 \\
\hline & $\mathrm{B} 20$ & 329 & 18.83 & 0.581 & 2.69 & 0.2365 & 4.50 \\
\hline & $\mathrm{B} 20$ & 345 & 18.36 & 0.485 & 2.97 & 0.2603 & 4.55 \\
\hline & B20 & 346 & 18.83 & 0.729 & 2.35 & 0.1961 & 4.65 \\
\hline & B20 & 347 & 18.57 & 0.754 & 2.36 & 0.2037 & 4.69 \\
\hline \multicolumn{3}{|l|}{ Average } & 18.65 & 0.625 & 2.63 & 0.2264 & 4.59 \\
\hline \multicolumn{3}{|c|}{ Standard deviation } & 0.19 & 0.10 & 0.28 & 0.02 & 0.08 \\
\hline \multicolumn{3}{|c|}{ Coefficient of variation } & $1.0 \%$ & $16.0 \%$ & $10.6 \%$ & $10.8 \%$ & $1.7 \%$ \\
\hline \multicolumn{3}{|c|}{ Percent difference with base: } & $-5.8 \%$ & $-28.3 \%$ & $-26.8 \%$ & $-17.4 \%$ & $-2.4 \%$ \\
\hline \multirow[t]{6}{*}{ Bus 2208} & Fuel & Run & $\begin{array}{c}\text { NOx } \\
\text { g/mile }\end{array}$ & $\begin{array}{c}\text { THC } \\
\text { g/mile }\end{array}$ & $\begin{array}{c}\text { CO } \\
\text { g/mile }\end{array}$ & $\begin{array}{c}\text { PM } \\
\text { g/mile }\end{array}$ & $\begin{array}{c}\text { Fuel } \\
\text { Economy } \\
\text { mpg }\end{array}$ \\
\hline & Base & 364 & 19.81 & 0.806 & 2.84 & 0.2178 & 4.67 \\
\hline & Base & 365 & 19.86 & 0.818 & 2.77 & 0.2001 & 4.67 \\
\hline & Base & 366 & 19.24 & 0.724 & 3.64 & 0.2901 & 4.57 \\
\hline & Base & 367 & 19.08 & 0.938 & 3.60 & 0.2804 & 4.60 \\
\hline & Base & 372 & 18.68 & 0.747 & 4.35 & 0.3358 & 4.52 \\
\hline \multicolumn{3}{|l|}{ Average } & 19.34 & 0.807 & 3.44 & 0.2648 & 4.60 \\
\hline \multicolumn{3}{|c|}{ Standard deviation } & 0.50 & 0.08 & 0.65 & 0.06 & 0.06 \\
\hline \multicolumn{3}{|c|}{ Coefficient of variation } & $2.6 \%$ & $10.3 \%$ & $18.9 \%$ & $21.0 \%$ & $1.4 \%$ \\
\hline & $\mathrm{B} 20$ & 358 & 19.01 & 0.542 & 3.18 & 0.2583 & 4.24 \\
\hline & $\mathrm{B} 20$ & 359 & 18.75 & 0.566 & 2.37 & 0.1933 & 4.33 \\
\hline & B20 & 360 & 18.47 & 0.546 & 2.93 & 0.2439 & 4.37 \\
\hline & $\mathrm{B} 20$ & 362 & 19.17 & 0.564 & 2.43 & 0.1581 & 4.44 \\
\hline & $\mathrm{B} 20$ & 377 & 18.33 & 0.533 & 3.61 & 0.3261 & 4.45 \\
\hline & B20 & 378 & 18.38 & 0.597 & 2.38 & 0.1868 & 4.59 \\
\hline & $\mathrm{B} 20$ & 379 & 18.20 & 0.616 & 2.53 & 0.1821 & 4.62 \\
\hline & B20 & 380 & 19.08 & 0.608 & 2.42 & 0.1714 & 4.55 \\
\hline \multicolumn{3}{|l|}{ Average } & 18.67 & 0.571 & 2.73 & 0.2150 & 4.45 \\
\hline \multicolumn{3}{|c|}{ Standard deviation } & 0.38 & 0.03 & 0.46 & 0.06 & 0.13 \\
\hline \multicolumn{3}{|c|}{ Coefficient of variation } & $2.0 \%$ & $5.6 \%$ & $16.9 \%$ & $26.4 \%$ & $3.0 \%$ \\
\hline \multicolumn{3}{|c|}{ Percent difference with base: } & -4.11 & -38.94 & -25.54 & -49.29 & -2.08 \\
\hline
\end{tabular}

